\title{
No licence for love versus same-sex relationships - partner relations and interpersonal commitment
}

\author{
Iwona Lidia Fanicka (1D \\ Institute of Psychology, University of Lodz, Lodz, Poland
}

\section{BACKGROUND}

Like heterosexual ones, homosexual partners strive to fulfil their needs for belonging and love. They also build their relationships in countries where less favourable public opinion exists towards same-sex relationships, due in part to the lack of equivalent legislation between heterosexual and non-heterosexual persons and couples. As opponents of such relationships claim them to be less stable and of lower quality, the current study examines whether the sexual orientation of partners may determine the quality of their relationship and their commitment to it.

\section{PARTICIPANTS AND PROCEDURE}

The study was conducted in a group of 530 cohabiting persons, aged 18-44 (230 persons with a homosexual orientation and 300 heterosexual) living in Poland. The participants were tested with three tools: a sociodemographic survey, the Polish version of the Partner Relations Ques- tionnaire by Halhweg, adapted by Janicka, and the Interpersonal Commitment Inventory (KZI) by Janicka and Szymczak: the Polish adaptation of the Commitment Inventory by Stanley and Markman.

\section{RESULTS}

The findings indicate that sexual orientation of women and men may influence their tendencies to change partners and their interpersonal commitment, interpreted as their dedication and obligation to stay in the relationship.

\section{CONCLUSIONS}

Some detailed analyses suggest that cohabitations between gay women portend better than those of gay men.

\section{KEY WORDS}

commitment; cohabitation; gay men; gay women; partnership relations

CORReSPonding AUthor - Prof. Iwona Lidia Janicka, Institute of Psychology, University of Lodz, 10/12 Smugowa Str., 91-433 Lodz, Poland, e-mail: iwona.janicka@uni.lodz.pl

AUthors' CONTRIBUtion - A: Study design - B: Data collection - C: Statistical analysis - D: Data interpretation .

E: Manuscript preparation · F: Literature search · G: Funds collection

TO CITE THIS ARTICLE - Janicka, I. L. (2021). No licence for love versus same-sex relationships - partner relations

and interpersonal commitment. Current Issues in Personality Psychology, 9(2), 101-113.

RECEIVED 04.10.2020 · REVIEWED 22.03.2021 · ACCEPTED 13.04.2021 · PUBLISHED 21.06.2021 


\section{BACKGROUND}

Close emotional relationships between same-sex persons are commonplace, not only in the countries where they are recognised by law, but also in those less open to such relations. Although around 4.5\% of people aged between 18 and 49 in Poland regard themselves as homosexual, the country occupies second place in Europe regarding negative, homophobic attitudes towards homosexual persons (ILGA Europe, 2019). Despite these attitudes and lack of legislation for same-sex relationships, some approximate data have indicated that from among the two million homosexual persons living in Poland, about half, i.e. one million, are in intimate relationships (Abramowicz, 2010; Mizielińska et al., 2014). A good example of the interest demonstrated by same-sex couples for legalization of their relationships may be found in the UK, where they recently gained the right to get married: following the legal recognition of samesex relationships in 2014, 15098 couples entered into marriage and 7732 of them changed their civil contract about partner relationship into marital union during the period March 2014 to March 2015 (Office for National Statistics, 2015).

Examining persons and couples with an orientation other than heterosexual is not easy. Although there are greater possibilities for conducting such studies in countries that allow for legalization of same-sex relationships, gaining access to this type of relationship may still be difficult. Moreover, when performing an evaluation of such relationships, it is necessary to consider their specific character, such as the fact that they exist within a heteronormative surrounding and certain conditions exist related to the sex of the partners.

The life of a same-sex couple is influenced by certain conditions that are formed in a particular social environment. Non-heterosexual persons are usually exposed to lack of acceptance and experience specific stressors, including minority stress, resulting in them limiting their social contacts and hiding the close relations away (Meyer, 2003). Same-sex relationships are hence typically deprived of social and cultural patterns of starting and maintaining contacts, are characterised by a greater range of freedom and acceptable behaviours and are usually based on negotiation. It is easier for heterosexual persons to form relationships as they learn strategies to make contacts and build close relationships during the process of socialisation and modelling. Further rituals related to maintaining the relationship, such as proposal, family introductions, engagement and wedding, are defined precisely. Furthermore, while expecting the relationship to be stable, and fear of social disapproval in case of its dissolution, may hinder heterosexual partners from splitting up, no such mechanism exists for same-sex relationships (Giddens, 2007; Majka-
Rostek, 2012). It may be possible that lack of acceptance from the heteronormative surroundings initiates a self-fulfilling prophesy resulting in the instability of same-sex relationships.

Such conditions are typically apparent in countries where legal recognition of same-sex relationships is not acceptable. In such countries, two categories of such relationships predominate: cohabitations and living apart together (LAT). The latter is usually chosen by partners who have not yet come out and would prefer to hide the relationship, or those who may not possess a self-contained flat where they could live together. They are together but live apart, an arrangement also known as a part-time relationship (Nave-Herz, 2002), a distance relationship or a distance love (Beck \& Beck-Gernsheim, 2016), classified as interrupted cohabitation, which is characterised by voluntary or unintentional separation (CrossBarnet et al., 2011). It is evidenced that cohabitations and LAT arrangements tend to be open, based upon emotional dependence only, and deprived of structural dependence, which does not favour their stability (Rhoades et al., 2006, 2012).

Relations between partners are determined by their sex-related needs, and these needs influence the specificity of same-sex relationships. Same-sex persons create two types of relationships: femalefemale and male-male couples, not just one, as is the case for heterosexual relationships. The onset of intimacy differs between gay and lesbian couples: female couples tend to be more restrictive with regard to their emotional and sexual dependencies and sexual exclusivity is usually maintained in the relationship; such relationships tend to be based upon loyalty and fidelity. In this case, the search for intimacy and sexual contacts continues over time and progresses more gradually: it typically starts with friendship, which may lead to love, and this love will initiate the formation of intimate contacts (Peplau \& Ghavami, 2009).

In the case of gay men, sexual contacts often occur during the first date (Majka-Rostek, 2012). Gay males tend to have more sexual partners than lesbians, and this has been attributed to their greater sexual needs (Holomberg \& Blair, 2009) and their tendencies toward polygamy (Da Silva Mendes \& Pereira, 2013; Julien et al., 2003; Vanderlaan \& Vasey, 2008). Yet, it ought to be observed that the possession of a large number of sexual partners may result not from sexual orientation but from being of male sex: men generally tend to display polygamous tendencies, regardless of sexual orientation (Buss, 2001), and heterosexual men also express a willingness to have short-living sexual contacts, this desire being held in check by the lower interests demonstrated by women in such contacts (Bailey et al., 1994). Thus, as their partners are also sex-oriented men, gay men are typically presented with greater opportunities 
for new and incidental sexual contacts. As the greater assimilability of new partners is related to their greater accessibility, gay couples tend to be more open; this entails greater acceptance for sex outside the relationship, and in this case, fidelity pertains more to the emotional sphere and it may not apply to sexual contacts (Buss, 2001; McClelland, 2013; Peplau \& Ghavami, 2009).

Because of this openness to new sexual contacts among gay men, most gay male couples define the sexual boundaries of the relationship. There may be agreements in which sexual contacts with other persons are accepted and those where such contacts are excluded. Among the former, an emphasis is placed on safety and protecting the partner from acquiring HIV infection. The need to use condoms was demanded. Some couples included some additional criteria to protect their relationship, such as a ban on repeating meetings with the same person or a ban on sleeping out; however, such rules are often broken and a partner usually does not admit it (Huebner et al., 2012). It appears that gay men who have some defined rules regarding sex with other men are more satisfied with their relationships than those who do not (Ramirez \& Brown, 2010).

To date, studies examining the quality of same-sex relationships are not unambiguous. Some of them show that same-sex partners are more satisfied with their relationships than heterosexual ones (Kurdek, 2008; Solomon et al., 2008). This is justified by the particular importance of closeness in non-heterosexual relationships, this being a factor which compensates for unfavourable confrontations with heterosexual persons and other menaces. Being engaged in a same-sex close relationship has been shown to have a positive effect on the mental health of partners (Whitton et al., 2018). In addition, a number of studies indicate that homosexual and heterosexual relationships are of similar quality; this applies to both non-legalized same-sex relationships and heterosexual marriages (Julien et al., 2003; Lew-Starowicz \& Lew-Starowicz, 2014; Roisman et al., 2008).

In spite of disapproval from the heteronormative surroundings, a steady growth in the number of samesex cohabitations, or maybe coming out, has recently been observed; however, few consistent studies have examined the quality and stability of these relationships. Previous findings indicate that homosexual couples tend to remain orientated towards new emotional relations, resulting in the relationships becoming less stable and favouring successive cohabitation (Da Silva Mendes \& Pereira, 2013; Goldberg et al., 2010; Huebner et al., 2012; Mizielińska et al., 2014; Solomon et al., 2008). Similar charges are levelled against heterosexual persons (Goodman \& Greaves, 2010; Lichter \& Qian, 2008).

Therefore, the aim of the present study is to examine whether cohabitation period and number of pre- vious relationships, indicating a tendency to change partners, as well as quality of partner relations and commitment to the relationship, depend on sexual orientation and sex. The following research questions were formed:

1. Do the cohabitation period of the current relationship and the number of previous relationships depend on sexual orientation and sex of the participants?

2. Does the quality of partner relations, i.e. mutual communication, intimacy and quarrelling behaviours, depend on the sexual orientation and sex of the participants?

3. Does interpersonal commitment, defined here as dedication and obligation, depend on sexual orientation and sex?

4. Which of the factors influencing the quality of partner relations (mutual communication, intimacy, quarrelling behaviours) may determine commitment as dedication and obligation to stay in the relationship?

An attempt was made to formulate hypotheses for the research questions.

It was found that the duration of the relationship and the number of relationships may depend on the sex and sexual orientation of the respondents (hypothesis 1). Making such an assumption is justified by the results of the research by DaSilva Mendes and Pereira (2013), Goldberg et al. (2010), Huebner et al. (2012), and Solomon et al. (2008). It was assumed that the average seniority of the relationship will depend on the sexual orientation and be different in women and men (hypothesis 1a), and similarly, the number of cohabitations will depend on the sexual orientation and be different in women and men (hypothesis 1b).

Selected variables concerning partnerships and interpersonal commitment have not been analysed in studies of same-sex couples so far. The results to date related to heterosexual couples and proved that the quality of partnerships depends on gender (Hahlweg, 1996; Janicka, 2008). On the other hand, the results regarding engagement are not conclusive. Research indicates that engagement does not depend on the gender of partners (Janicka \& Szymczak, 2019), and also shows that gender may only be relevant in relation to one of the dimensions of commitment, i.e. obligation. Women reveal greater obligation - they see more restrictions on leaving a relationship than men (Baxter et al., 2010). It was assumed that the means concerning the dimensions of partnerships will depend on sexual orientation and be different in women and men, which implies the existence of interactions between sexual orientation and gender (hypothesis 2). However, with regard to interpersonal commitment, no such interaction was anticipated, which means that commitment does not depend on sexual orientation and gender (hypothesis 3). It was also recognised that the dimensions of partnership 
relations (mutual communication, intimacy, quarrelling behaviours) will prove to be significant for interpersonal commitment as dedication and obligation (hypothesis 4).

\section{PARTICIPANTS AND PROCEDURE}

\section{PARTICIPANTS}

The study included 530 cohabiting persons of Polish nationality and living permanently in Poland. The examined group comprised 230 persons who identified themselves as homosexual (150 men and 80 women) and were in same-sex relationships. The control group included 300 persons (150 men and 150 women) who declared themselves to be heterosexual. All participants were aged between 18 and 44. Persons from the examined and control groups were homogeneous with regard to age; this applied to homosexual $(M=28.84$, $S D=6.01)$ and heterosexual women $(M=28.38$, $S D=7.02)$, and to homosexual $(M=28.33, S D=6.31)$ and heterosexual men $(M=29.45, S D=6.07) ; p=.118$.

The participants studied and/or were in employment. Among the homosexual men, 74\% had completed higher education, $23.3 \%$ secondary education and $2.7 \%$ only primary education, with the respective figures being $70 \%, 30 \%$ and $0 \%$ for the women. Likewise, among the heterosexual men, $66 \%$ had completed higher education, 30\% secondary education and $3.3 \%$ primary education, with the respective figures for women being $56 \%, 39 \%$ and $4.7 \%$. Although no dependence was found between sexual orientation of men and education level ${ }^{1}(p=.365)$, one was present among women $(p=.033)$. The cohabitation period of their current relationships ranged from two to 72 months, and the number of previous relationships from none to seven.

\section{PROCEDURE}

Recruitment was performed in the years 2018-2019 using snow ball and social media. Participants were presented with the purpose of the research and information on how it would be carried out. All persons consciously agreed to participate in the study. All the procedures carried out in the human studies were in accordance with the required ethical standards.

The study required taking into account - considering the purpose of the research - important inclusion variables (age: from 18 to 44 years; gender; having a permanent partner: cohabitation) and exclusion variables (a lonely life - without a partner). The respondents were informed about the possibility of contacting the researcher in order to obtain additional information as well as possible psychological help or support.

\section{MEASURES}

The study was performed using a sociodemographic survey and two questionnaires for examining partner close relationships, namely the Partner Relations Questionnaire, i.e. the Polish adaptation of Partnerschaftsfragebogen (testing the quality of the relationship) by Hahlweg (Janicka, 2008), and the Interpersonal Commitment Inventory (KZI), i.e. the Polish adaptation of the Commitment Inventory (study of commitment in the relationship) by Stanley and Markman (Janicka \& Szymczak, 2017).

The sociodemographic survey included questions regarding sex, age, education, sexual orientation, nationality, cohabitation period with current partner, and the number of previous relationships.

The Partner Relations Questionnaire (KSP) contains 30 statements and is designed to examine the quality of a relationship; it may be also used to diagnose disorders in relations between partners. The KSP consists of three scales: mutual communication (showing interest, open talking and listening to the partner, planning things together, paying compliments; e.g. "We plan to spend free time together"; "He/she talks to me openly about his/her thoughts and feelings"); intimacy (caressing, hugging, fulfilling sexual needs, talking about feelings, talking about sexual needs; e.g. "He/she tells me that he/she likes me"; "He/she responds positively to my sexual needs"); and quarrelling behaviours (blaming, laughing at the partner, criticizing, reminding the partner of their mistakes, insults, restricting the partner's personal freedom; e.g. "He/she argues with me about any trifle"; "He/ she criticizes me in a malicious, ironic way"). Each of the statements is rated on a four-point scale, from 0 (never) to 3 (very often) (Hahlweg, 1996; Janicka, 2008). The reliability of the Partnership Questionnaire was assessed using the Cronbach's $\alpha$ coefficient. The tested three dimensions were characterized by satisfactory internal consistency and amounted to: .85 (mutual communication), .83 (intimacy) and .89 (behaviour in quarrels).

The Interpersonal Commitment Inventory (KZI), consisting of 19 items, allows three factors of commitment to be measured: bond with the partner ("I want to be with my partner always"), comprising items concerning emotional closeness with the partner; significance of the relationship, examining whether the relationship is being treated seriously and not acknowledging its ending; concern for the partner's well-being ("I must/should stay in the relationship") allows the feeling of being kept or even trapped in the relationship to be defined. As in the original version of the method (Stanley \& Markman, 1992), the Polish version distinguishes two dimensions of commitment: dedication and constraint commitment (or obligation). The two factors used in the previous version, viz. the bond with the partner and signifi- 
cance of the relationship, correspond to the construct of dedication, which determines the will to maintain the relationship. The third factor, i.e. concern for the partner's well-being, corresponds to the construct of obligation: "I must/should stay in the relationship" and allows the stability of the relationship to be predicted. This factor may be considered as universal for all obligations regarding staying in a relationship which are associated with some expected losses. Hence, obligation is referred to as a good predicator of the stability of the relationship. The questionnaire consists of a number of statements which are graded on a 7-point scale from 1 (I strongly disagree) to 7 (I strongly agree). The Interpersonal Commitment Inventory has been found to display good psychometric properties, making it a valid and reliable tool. The reliability of the KZI was assessed using Cronbach's $\alpha$. The examined factors were characterised by satisfactory internal consistency ranging from .71 to .89 (.71 - significance of the relationship; .76 - concern for the partner's well-being; 89 - bond with the partner). The questionnaire can be used to diagnose people in engagement, marital and cohabitation relationships - both heterosexual and homosexual (Janicka \& Szymczak, 2017).

\section{RESULTS}

The analysis examined whether sexual orientation and sex may correspond to the length of a typical relationship, the number of close emotional relationships, quality of partner relations, and commitment to the relationship. The data analysis was performed using two-way analysis of variance (sexual orientation, sex) with a main effect test (Winer et al., 1991).

The sizes of the effect were assessed by referring to the ranges assumed for the parameter $\eta^{2}$. No effect: $\eta^{2}<.01$, weak effect: $.01 \leq \eta^{2}<.06$, moderate effect: $.06 \leq \eta^{2}<.14$, strong effect: $\eta^{2} \geq .14$ (Sink \& Mvududu, 2010).
The estimation of potential covariance variable, i.e. the period of the relationship (measured in months) with regard to sexual orientation and sex, is presented in Table 1.

Cohabitation between gay women was found to last significantly longer than those with heterosexual women $\left(p<.001\right.$; strong effect $\left.-\eta_{\mathrm{p}}^{2}=.21\right)$ and those of gay men $\left(p<.001\right.$; strong effect $\left.-\eta_{\mathrm{p}}^{2}=.20\right)$. While same sex relationships between gay men tend to be shorter than those between lesbians, they are of a similar length to relationships between heterosexual men and women. Cohabitations reported by heterosexual women and men are of equal length $(p>.05)$. An interaction was found between sex and sexual orientation (moderate effect $-\eta_{p}^{2}=.12$ ), i.e. the dependence of mean relationship duration on sexual orientation differs between women and men. This is the basis for accepting hypothesis $1 \mathrm{a}$.

Table 2 presents the results of the estimation of the potential covariance variable, i.e. the number of cohabitations, with regard to sexual orientation and sex.

Homosexual and heterosexual respondents differ with regard to their number of previous relationships, as do gay men and gay women $(p<.001)$ : gay men had more previous relationships than heterosexual ones (strong effect $-\eta_{\mathrm{p}}^{2}=.21$ ) and gay women reported fewer previous relationships than heterosexual respondents (weak effect $-\eta_{\mathrm{p}}^{2}=.03$ ) and gay men (strong effect $-\eta_{\mathrm{p}}^{2}=.25$ ). Heterosexual women and men are homogeneous with regard to the number of their relationships.

An interaction was identified between sexual orientation and sex (strong effect $-\eta^{2}=.17$ ), indicating that the dependence of the number of cohabitations on sexual orientation differs between women and men. This is the basis for accepting hypothesis $1 \mathrm{~b}$.

Thus, it has been assumed that the duration and the number of previous relationships may increase the likelihood of the relationship disintegration, though the two variables may be interrelated. Studies to date (Brown \& Booth, 1996; Mortensen et al., 2012;

\section{Table 1}

Sexual orientation and sex as related to homosexual and heterosexual cohabitation period (measured in months)

\begin{tabular}{|c|c|c|c|c|c|c|}
\hline \multirow[t]{3}{*}{ Sex } & \multicolumn{4}{|c|}{ Orientation } & \multirow{3}{*}{$\begin{array}{c}p \text { in main effect test } \\
\text { (between orientations) }\end{array}$} & \multirow[t]{3}{*}{$\eta_{\mathrm{p}}^{2}$} \\
\hline & \multicolumn{2}{|c|}{ Gay } & \multicolumn{2}{|c|}{ Heterosexual } & & \\
\hline & $M$ & $S E$ & $M$ & $S E$ & & \\
\hline Women & 32.48 & 18.36 & 13.18 & 9.62 & $<.001$ & .21 \\
\hline Men & 13.97 & 12.97 & 12.79 & 7.41 & .388 & .00 \\
\hline $\begin{array}{l}p \text { in main effect test } \\
\text { (between sexes) }\end{array}$ & \multicolumn{2}{|c|}{$<.001$} & \multicolumn{2}{|c|}{.777} & $\begin{array}{c}p \text { in interaction effect test: } \\
\text { sexual orientation } \times \text { sex }<.001\end{array}$ & .12 \\
\hline$\eta_{p}^{2}$ & \multicolumn{2}{|c|}{.20} & \multicolumn{2}{|c|}{.00} & & \\
\hline
\end{tabular}


Smock, 2000; Stanley et al., 2006; Xu et al., 2006) indicate that the number of close relationships formed by a partner is inversely related to the chances of the next relationship being a stable one: the more relationships, the less stable subsequent ones become. Thus, it has been assumed that the duration and the number of previous relationships may influence the quality of partner relations and commitment.

The study estimates the quality of partner relations (mutual communication, intimacy, and behaviours in quarrel) according to sexual orientation and sex. Table 3 presents means $(M)$, standard error $(S E)$ and

Table 2

Sexual orientation and sex as related to number of cohabitations

\begin{tabular}{|c|c|c|c|c|c|c|}
\hline \multirow[t]{3}{*}{ Sex } & \multicolumn{4}{|c|}{ Orientation } & \multirow{3}{*}{$\begin{array}{c}p \text { in main effect test } \\
\text { (between orientations) }\end{array}$} & \multirow{3}{*}{$\eta_{p}^{2}$} \\
\hline & \multicolumn{2}{|c|}{ Gay } & \multicolumn{2}{|c|}{ Heterosexual } & & \\
\hline & $M$ & $S E$ & $M$ & $S E$ & & \\
\hline Women & 0.90 & 0.88 & 1.55 & 1.00 & $<.001$ & .03 \\
\hline Men & 3.13 & 1.55 & 1.48 & 1.17 & $<.001$ & .21 \\
\hline $\begin{array}{l}p \text { in main effect test } \\
\text { (between sexes) }\end{array}$ & \multicolumn{2}{|c|}{$<.001$} & \multicolumn{2}{|c|}{.634} & $\begin{array}{c}p \text { in interaction effect test: } \\
\text { sexual orientation } \times \text { sex }<.001\end{array}$ & .17 \\
\hline$\eta_{p}^{2}$ & \multicolumn{2}{|c|}{.25} & \multicolumn{2}{|c|}{.00} & & \\
\hline
\end{tabular}

Table 3

Sexual orientation and sex as related to partner relations (mutual communication, intimacy, quarrelling behaviours). Covariance variables: the period of the relationship and the number of cohabitations

\begin{tabular}{|c|c|c|c|c|c|c|}
\hline \multirow[t]{3}{*}{ Sex } & \multicolumn{4}{|c|}{ Orientation } & \multirow{3}{*}{$\begin{array}{c}p \text { in main effect test } \\
\text { (between orientations) }\end{array}$} & \multirow[t]{3}{*}{$\eta_{\mathrm{p}}^{2}$} \\
\hline & \multicolumn{2}{|c|}{ Gay } & \multicolumn{2}{|c|}{ Heterosexual } & & \\
\hline & M & $S E$ & M & $S E$ & & \\
\hline \multicolumn{7}{|c|}{ Mutual communication } \\
\hline Women & 23.47 & 0.66 & 21.04 & 0.42 & .002 & .02 \\
\hline Men & 20.77 & 0.47 & 19.52 & 0.42 & .053 & .01 \\
\hline $\begin{array}{l}p \text { in main effect test } \\
\text { (between sexes) }\end{array}$ & \multicolumn{2}{|c|}{.002} & \multicolumn{2}{|c|}{.009} & $\begin{array}{l}p \text { in interaction effect test: } \\
\text { orientation } \times \text { sex }=.264\end{array}$ & .00 \\
\hline$\eta_{\mathrm{p}}^{2}$ & \multicolumn{2}{|c|}{.02} & \multicolumn{2}{|c|}{.01} & & \\
\hline \multicolumn{7}{|c|}{ Intimacy } \\
\hline Women & 23.58 & 0.65 & 21.42 & 0.41 & .005 & .02 \\
\hline Men & 23.11 & 0.46 & 22.24 & 0.41 & .173 & .00 \\
\hline $\begin{array}{l}p \text { in main effect test } \\
\text { (between sexes) }\end{array}$ & \multicolumn{2}{|c|}{.581} & \multicolumn{2}{|c|}{.148} & $\begin{array}{l}p \text { in interaction effect test: } \\
\text { orientation } \times \text { sex }=.210\end{array}$ & .00 \\
\hline$\eta_{p}^{2}$ & \multicolumn{2}{|c|}{.00} & \multicolumn{2}{|c|}{.00} & & \\
\hline \multicolumn{7}{|c|}{ Quarrelling behaviours } \\
\hline Women & 7.30 & 0.68 & 6.51 & 0.43 & .329 & .00 \\
\hline Men & 9.82 & 0.48 & 7.11 & 0.43 & $<.001$ & .03 \\
\hline $\begin{array}{l}p \text { in main effect test } \\
\text { (between sexes) }\end{array}$ & \multicolumn{2}{|c|}{.005} & \multicolumn{2}{|c|}{.313} & $\begin{array}{l}p \text { in interaction effect test: } \\
\text { orientation } \times \operatorname{sex}=.077\end{array}$ & .01 \\
\hline$\eta_{p}^{2}$ & \multicolumn{2}{|c|}{.02} & \multicolumn{2}{|c|}{.00} & & \\
\hline
\end{tabular}


effect size $\left(\eta_{\mathrm{p}}^{2}\right)$. Means are adjusted by the period of the relationship and the number of cohabitations.

Mutual communication in a relationship was better perceived by homosexual women than by heterosexual and gay women $(p<.05$; weak effect $\left.-\eta_{p}^{2}=.02\right)$. Mutual communication is differentiated by sex among heterosexual respondents: it is better perceived by women than men $(p<.05$; weak effect $\left.-\eta_{p}^{2}=.02\right)$. It ought to be noted that open talking and listening to the partner, planning things together and paying compliments were assessed more highly by gay women and heterosexual women than gay men and heterosexual men, whose estimations were similar.

Physical and verbal expressions of intimacy in a close relationship were reported significantly more frequently by gay women than heterosexual women $\left(p<.05\right.$; weak effect $\left.-\eta_{\mathrm{p}}^{2}=.02\right)$; however, intimacy did not differentiate gay women and gay men or heterosexual women and men.

Negative verbal and nonverbal communication was reported significantly more often in the relation- ships made by homosexual men than heterosexual men $\left(p<.05\right.$; weak effect $\left.-\eta_{\mathrm{p}}^{2}=.03\right)$, or homosexual women $\left(p<.05\right.$; weak effect $\left.-\eta_{\mathrm{p}}^{2}=.02\right)$. No significant differences were found between gay women and heterosexual women or between heterosexual women and men regarding their quarrelling behaviours.

Sexual orientation differentiates communication and intimacy among women, and differentiates quarrelling behaviours among men. Sex differentiates mutual communication for both the homosexual and heterosexual respondents, and differentiates quarrelling behaviours among homosexual participants. However, no interaction between sexual orientation and sex was observed $(p>.05)$. Hypothesis 2 should be rejected.

Commitment was also analysed as dedication (emotional bond and significance of the relationship) and obligation (concern for the partner's well-being) according to sexual orientation and sex. Table 4 presents means $(M)$, standard error $(S E)$ and effect size $\left(\eta_{\mathrm{p}}^{2}\right)$. Means are adjusted by the period of the relationship and the number of cohabitations.

\section{Table 4}

Sexual orientation and sex as related to commitment, estimated as dedication (emotional bond and significance of the relationship) and obligation (concern for the partner's well-being). Covariance variables: the period of the relationship and the number of cohabitations

\begin{tabular}{|c|c|c|c|c|c|c|}
\hline \multirow[t]{3}{*}{ Sex } & \multicolumn{4}{|c|}{ Orientation } & \multirow{3}{*}{$\begin{array}{l}p \text { in main effect test } \\
\text { (between orientations) }\end{array}$} & \multirow[t]{3}{*}{$\eta_{\mathrm{p}}^{2}$} \\
\hline & \multicolumn{2}{|c|}{ Gay } & \multicolumn{2}{|c|}{ Heterosexual } & & \\
\hline & $M$ & $S E$ & $M$ & $S E$ & & \\
\hline \multicolumn{7}{|c|}{ Emotional bond (dedication) } \\
\hline Women & 52.85 & 1.14 & 49.48 & 0.80 & .043 & .00 \\
\hline Men & 47.20 & 0.91 & 50.01 & 0.81 & .009 & .01 \\
\hline $\begin{array}{l}p \text { in main effect test } \\
\text { (between sexes) }\end{array}$ & \multicolumn{2}{|c|}{.003} & \multicolumn{2}{|c|}{.195} & $\begin{array}{l}p \text { in interaction effect test: } \\
\text { orientation } \times \text { sex }=.006\end{array}$ & .01 \\
\hline$\eta_{p}^{2}$ & \multicolumn{2}{|c|}{.01} & \multicolumn{2}{|c|}{.00} & & \\
\hline \multicolumn{7}{|c|}{ Significance of the relationship (dedication) } \\
\hline Women & 21.91 & 0.81 & 19.87 & 0.51 & .004 & .01 \\
\hline Men & 25.59 & 0.57 & 19.97 & 0.51 & $<.001$ & .09 \\
\hline $\begin{array}{l}p \text { in main effect test } \\
\text { (between sexes) }\end{array}$ & \multicolumn{2}{|c|}{.001} & \multicolumn{2}{|c|}{.885} & $\begin{array}{l}p \text { in interaction effect test: } \\
\text { orientation } \times \text { sex }=.006\end{array}$ & .02 \\
\hline$\eta_{\mathrm{p}}^{2}$ & \multicolumn{2}{|c|}{.02} & \multicolumn{2}{|c|}{.00} & & \\
\hline \multicolumn{7}{|c|}{ Concern for the partner's well-being (obligation) } \\
\hline Women & 16.99 & 0.44 & 15.53 & 0.27 & .005 & .02 \\
\hline Men & 17.61 & 0.31 & 12.89 & 0.28 & $<.001$ & .19 \\
\hline $\begin{array}{l}p \text { in main effect test } \\
\text { (between sexes) }\end{array}$ & \multicolumn{2}{|c|}{.284} & \multicolumn{2}{|c|}{$<.001$} & $\begin{array}{l}p \text { in interaction effect test: } \\
\text { orientation } \times \text { sex }=.001\end{array}$ & .04 \\
\hline$\eta_{\mathrm{p}}^{2}$ & \multicolumn{2}{|c|}{.00} & \multicolumn{2}{|c|}{.08} & & \\
\hline
\end{tabular}


Gay women assessed the emotional bond in their relationships more highly than gay men and heterosexual women $(p<.05)$. Relationships formed by heterosexual men demonstrate a stronger emotional bond than those observed among gay men $(p<.05$; weak effect $\left.-\eta_{\mathrm{p}}^{2}=.01\right)$, but similar to the those formed by heterosexual women $(p>.05)$.

Gay men attributed greater significance to their relationships than heterosexuals $(p<.001$; moderate effect $\left.-\eta_{p}^{2}=.09\right)$. Gay men acknowledged their relationships as being more significant than lesbians $\left(p<.01\right.$; weak effect $\left.-\eta_{\mathrm{p}}^{2}=.02\right)$, while heterosexual respondents attributed similar significance to their relationships.

Gay men and lesbians tended to demonstrate a stronger obligation to stay in the relationship, expressed as concern for the partner's well-being, than heterosexual men and women $(p<.05$; strong effect $-\eta_{\mathrm{p}}^{2}=.19$ and moderate effect $-\eta_{\mathrm{p}}^{2}=.02$ ). Among heterosexual respondents, women refrained from leaving the relationship more than men $(p<.001$; moderate effect $-\eta_{\mathrm{p}}^{2}=.08$ ).

The sexual orientation of women and men differentiates all three studied commitment factors. Gender differentiates homosexual persons with regard to dedication (emotional bond and significance of the relationship) and heterosexual persons with regard to obligation (concern for the partner's well-being).
An interaction was found between sexual orientation and sex (moderate effect $-\eta_{p}^{2}=.04$ ), indicating that the dependences of interpersonal commitment on sexual orientation differ between men and women. Hypothesis 3, which did not assume such an interaction, should be rejected.

Further analyses using linear regression models (Draper \& Smith, 1998) were performed to estimate the influence of the dimensions of relationship quality (mutual communication, intimacy, and behaviours in quarrel) upon commitment, interpreted as the dedication (emotional bond and significance of the relationship) and obligation felt by a partner to stay in the relationship, expressed as concern for the partner's well-being ${ }^{2}$.

Analyses showed that the partner relations (mutual communication, intimacy, and behaviours in quarrel) do not affect dedication, i.e. the bond with a partner and serious treatment of the relationship. Therefore, only the results regarding dimensions of partner relations and obligation (concern for the partner's well-being) are presented further. Table 5 shows the results.

Mutual communication strengthens the obligation to stay in the relationship among gay women $(p<.001$; moderate effect $-R$ partial $=.41)$ and gay men, and among heterosexual men $(p<.05$; weak effect $-R$ partial $=.21$ and $R$ partial $=-.25)^{3}$.

Table 5

Mutual communication, intimacy, and quarrelling behaviours related to obligation (concern for the partner's well-being) in gay women and gay men and heterosexual men and women

\begin{tabular}{|c|c|c|c|c|c|c|}
\hline & $\begin{array}{l}\text { Absolute } \\
\text { term }\end{array}$ & $\begin{array}{c}\text { Regression } \\
\text { coefficient B }\end{array}$ & $\begin{array}{c}\text { Standard } \\
\text { deviation B }\end{array}$ & $\begin{array}{l}p \text { in regression } \\
\text { coefficient } B \text { test }\end{array}$ & $R$ raw & $R$ partial \\
\hline \multicolumn{7}{|c|}{ Mutual communication } \\
\hline Gay women & 11.55 & .23 & .06 & $<.001$ & .42 & .41 \\
\hline Heterosexual women & 16.24 & .04 & .05 & .345 & .12 & .08 \\
\hline Gay men & 15.46 & .14 & .05 & .010 & .19 & .21 \\
\hline Heterosexual men & 19.99 & .20 & .06 & .002 & -.26 & -.25 \\
\hline \multicolumn{7}{|c|}{ Intimacy } \\
\hline Gay women & 12.32 & .21 & .06 & .001 & .38 & .37 \\
\hline Heterosexual women & 12.73 & .14 & .05 & .003 & .24 & .14 \\
\hline Gay men & 18.45 & -.01 & .05 & .842 & -.02 & -.02 \\
\hline Heterosexual men & 14.88 & .05 & .07 & .489 & .10 & .06 \\
\hline \multicolumn{7}{|c|}{ Quarrelling behaviours } \\
\hline Gay women & 20.52 & -.45 & .03 & $<.001$ & -.84 & -.84 \\
\hline Heterosexual women & 17.52 & -.04 & .06 & .468 & -.09 & -.06 \\
\hline Gay men & 21.01 & -.56 & .03 & $<.001$ & -.87 & -.86 \\
\hline Heterosexual men & 16.27 & -.04 & .06 & .488 & -.03 & -.06 \\
\hline
\end{tabular}


Intimacy appears to be significant for the stability of relationships among both homosexual $(p<.01$; weak effect $-R$ partial $=.37)$ and heterosexual women $(p<.05$; weak effect $-R$ partial $=.14)$ : greater intimacy is associated with greater concern for the partner and hence anxiety regarding the greater losses associated with leaving the relationship.

The obligation to stay in the relationship depends on quarrelling behaviours, and this applied to both gay women $(p<.001$; strong effect $-R$ partial $=-.84)$ and gay men $(p<.001$; strong effect $-R$ partial $=-.86)$. The presence of fewer quarrelling behaviours was associated with greater concern for the partner, and a significantly lower risk of leaving the relationship. Hypothesis 4 was confirmed regarding one of the dimensions of commitment - obligation.

\section{DISCUSSION}

A number of the study participants were homosexual residents of Poland, whose government refrains from introducing legislation for same-sex couples and their relationships, evoking anxiety and even aggression from heterosexuals. This policy is based on a belief that same-sex relationships are not only improper, but also portend badly for the future, because of a perceived low quality and instability. Therefore, the aim of the present study was to estimate the close emotional relationships of cohabiting homosexual partners and compare them with heterosexual cohabitations. The study also examined the length of the current relationship, the number of previous relationships declared by the examinees, and the quality of partner relations and commitment to the relationship.

The findings indicate that the dependence of relationship length and number of relationships on sexual orientation differs between men and women: gay women reported a longer current relationship and fewer previous relationships than heterosexual women and gay men. By contrast, Kurdek (2004) noted an opposite tendency, stating that lesbian cohabitations dissolve more often (18\%) than cohabitations between gay men (13\%), with these findings also applying to legalised relationships. Elsewhere, some data contained in the Population Register System in Norway and Sweden, where every change in marital status is noted, indicate that the risk of divorce is twice as high for lesbians as it is for gay men in both countries (Andersson et al., 2006); this is attributed to a lack of tolerance for infidelity in lesbian couples and consent to it among gay men.

Significantly more cohabitation was observed in gays (compared to lesbians and heterosexual men), which may indicate a tendency to change partners and threaten the stability of close relationships. This is confirmed by the majority of previous reports ( $\mathrm{Da}$
Silva Mendes \& Pereira, 2013; Goldberg et al., 2010; Huebner et al., 2012; Mizielińska et al., 2014), including longitudinal studies (Solomon et al., 2008), which indicate that relationships between gay man are shorter and are less stable than lesbian relationships, due to their open character and reduced sexual exclusivity.

Successive cohabitations may have a negative impact on relationship commitment and lower the chances for stability in a subsequent relationship. This is related to perceiving a relationship as temporary and open, which is defined as the cohabitation effect. Partners with numerous cohabitations typically leave relationships when some difficulties or misunderstandings occur (Cohan \& Kleinbaum, 2002; Kline et al., 2004; Rhoades et al., 2012; Stanley et al., 2006). Our findings confirm that the duration of the relationship and the number of cohabiting partners can have an impact on partnerships and interpersonal engagement.

Partnership relationships (in terms of communication and intimacy), assessed taking into account the duration of the relationship and the number of relationships, were perceived as better by homosexual women compared to heterosexual women and gays. Similar outcomes among lesbians were obtained by Julien et al. (2003), while negative communication was more dominant in relationships between gay men than between lesbians or heterosexuals. It tended to manifest itself in blaming or criticizing one another, using nasty comments, insults or irony, laughing at the partner, reminding the partner of their mistakes and 'twisting the partner's words', as well as undesirable physical behaviours such as pushing, poking and throwing objects. The more conflictual nature of relationships between gay men has been confirmed in other studies (Julien et al., 2003; Kurdek, 2005; Solomon et al., 2008). Similarities have been found between gay men and heterosexual men regarding communication and intimacy, and also between gay women and heterosexual women, for whom similarly low scores have been observed regarding negative behaviour in a quarrel. Most studies indicate that sexual orientation does not influence the quality of the relationship (Cusack et al., 2012; Roisman et al., 2008; Świder \& Winiewski, 2017; Whitton et al., 2015).

Any full examination of close relationships also requires an evaluation of interpersonal commitment. This is regarded as indispensable in building and strengthening a relationship between partners and one that is reflected as the will and/or obligation to stay in the relationship (Rhoades et al., 2012). Commitment perpetuates the relationships of both happy and unhappy couples (Pryor \& Roberts, 2005). Numerous studies on heterosexual couples indicate that cohabitation does not portend well for commitment (Hsueh et al., 2009; Rhoades et al., 2012; Stanley 
\& Markman, 1992; Stanley et al., 2004). The present study also indicates that, as well as the form of the relationship, the sexual orientation and sex of the partners also play key roles in commitment, interpreted as the will (emotional bond and significance of the relationship) and obligation (concern for the partner) to stay in the cohabiting relationship; in addition, lesbians appear to display greater emotional closeness than gay men and heterosexual women.

Gay men were also found to demonstrate lower emotional closeness with their partner than heterosexual men; this is confirmed by previous studies indicating that such relationships tend to be more sexual than emotional, with the emotional bond not serving as the uniting factor for same-sex relationships between men (Julien et al., 2003; Vanderlaan \& Vasey, 2008). Relationships based only on sexual satisfaction can be fragile (Huebner et al., 2012), as confirmed by the present findings indicating that gay men have the largest numbers of relationships out of those interviewed. The fact that gay men tend to have so many relationships may paradoxically result in the fact that the latest one is especially important for them; hence, similarly to lesbians, they tend to attribute high significance to the current relationship, which is accompanied by concern for their partner and the need to maintain a close relationship. However, a deeper examination of our results rejects this conclusion because the relationship is based on both dedication and obligation. These two structures of commitment, while separate, work together to stabilize the relationship (Givertz et al., 2016; Stanley \& Markman, 1992). It is advantageous when a person feels that both he or she wants to be in the relationship, i.e. feels an emotional bond with the partner and strives to be with the partner in the relationship, but also feels an obligation to stay, i.e. the person cannot leave the partner or is anxious about it. It is shown that women commit themselves to a stable relationship to a greater extent than men (Baxter et al., 2010). In the present study, this was more distinct with homosexual women than with heterosexual women. A favourable prognosis for the stability of lesbian relationships depends on intimacy, mutual communication and a low level of conflict. The latter two factors can also determine the stability of gay men's relationships. However, it is the low level of conflicting behaviour that is the most favourable for homosexual relationships (strong effect). In turn, the stability of heterosexual cohabitation may be influenced by mutual communication and intimacy among partners.

Nowadays, pressure to legalise same-sex relationships is growing; this is related to the greater mutual commitment of the partners, but also to greater social support for such a relationship. Adult men and women who are in legalised same-sex relationships are found to be more satisfied and their relations are more stable than those from non-legalised relationships (Andersson et al., 2006; Julien et al., 2003; Kurdek, 2004; McLanahan \& Beck, 2010; Solomon et al., 2008; Whitton et al., 2015). Lack of social acceptance and adequate legislation for same-sex relationships results in same-sex couples living together in secret, without any sense of long-term security or dependence concerning inter alia financial matters, inheritance rights or mutual care, which may weaken relations between the partners.

The present research is not without limitations. Undoubtedly, they are related to the non-random selection of the group and the analysis of the results, which was carried out in the correlation paradigm. Participants included single persons and not couples, and they had not been verified regarding their possible coming out. Relations between partners who have come out may be different from those between partners who have not. The latter situation usually occurs in countries where same-sex relationships are not recognized by law. The fears experienced by homosexual partners related to their functioning in a heteronormative society may also play a significant role in their close relations. Moreover, the respondents were not asked whether they treated their relationships as sexually exclusive, which would allow the assessment of their significance. It is important to conduct further studies including legalised relationships of gays and lesbians. The form of a relationship defines the character of partners' expectations and creates a specific social context for their functioning.

\section{ENDNOTES}

1 The chi-square test was used to assess the relation. 2 A separate model was built for each relationship quality indicator.

3 In linear regression models, the value of the $R$ partial coefficient illustrates the strength of the relationship between the dependent variable and the explanatory variable after removing the influence of the 'disturbing' variables, i.e. the number of relationships and the duration of the relationship, both from the dependent variable and the explanatory variable.

\section{REFERENCES}

Abramowicz, M. (2010). Wprowadzenie do problematyki raportu [Introduction to the problems of the report]. In M. Zima (Ed.), Tęczowe rodziny w Polsce. Prawo a rodziny lesbijskie i gejowskie [Rainbow families in Poland. Law and lesbian and gay families] (pp. 7-11). Kampania Przeciw Homofobii. 
Andersson, G., Noack, T., Seierstad, A., \& WeedonFekjar, H. (2006). The demographics of same-sex marriages in Norway and Sweden. Demography 43, 79-98. https://doi.org/10.1353/dem.2006.0001

Bailey, J. M., Gaulin, S., Agyei, Y., \& Gladue, B. A. (1994). Effects of gender and sexual orientation on evolutionarily relevant aspects of human mating psychology. Journal of Personality and Social Psychology, 66, 1081-1093. https://doi.org/10.1037// 0022-3514.66.6.1081

Baxter, J., Haynes, M., \& Hewitt, B. (2010). Pathways into marriage: Cohabitation and the domestic division of labour. Journal of Family Issues, 31, 15071529. https://doi.org/10.1177/0192513X10365817

Beck, U., \& Beck-Gernsheim, E. (2016). Miłość na odlegtość [Distance love]. PWN.

Buss, D. (2001). Psychologia ewolucyjna [Evolutionary psychology]. Gdańskie Wydawnictwo Psychologiczne.

Brown, S. I., \& Booth, A. (1996). Cohabitation versus marriage: a comparison of relationship quality. Journal of Marriage and the Family, 58, 668-678. https://doi.org/10.2307/353727

Cohan, C. L., \& Kleinbaum, S. (2002). Toward a greater understanding of the cohabitation effect: Premarital cohabitation and marital communication. Journal of Marriage and the Family, 64, 180-192. https://doi.org/10.1111/j.1741-3737.2002.00180.x

Cross-Barnet, C., Cherlin, A., \& Burton, L. (2011). Bound by children: Intermittent cohabitation and living together apart. Family Relations, 60, 633-647. https://doi.org/10.1111/j.1741-3729.2011.00664.x

Cusack, C. E., Hughes, J. L., \& Cook, R. (2012). Components of love and relationship satisfaction: Lesbians and heterosexual women. Psi Chi Journal of Psychological Research, 17, 171-179. https://doi. org/10.24839/2164-8204.JN17.4.171

Da Silva Mendes, J. C., \& Pereira, H. M. (2013). Monogamy and marital adjustment: a study of same sex couples and different sex couples. Psychology, Community \& Health, 2, 1-19. https://doi.org/ 10.5964/pch.v2i 1.19

Draper, N. R., \& Smith, H. (1998). Applied regression analysis. Third edition. John Wiley \& Sons.

Giddens, A. (2007). Przemiany intymności. Seksualność, miłość, erotyzm we wspótczesnych spoteczeństwach [Transformations of intimacy. Sexuality, love, eroticism in contemporary societies]. Wydawnictwo Naukowe PWN.

Givertz, M., Burke, T., Segrin, C., \& Woszidlo, A. (2016). Attachment orientation moderates the relationship between dedication and constraint commitment and felt constraint in married couples. Couple and Family Psychology: Research and Practice, 5, 1-11. https://doi.org/10.1037/cfp0000052

Goldberg, A. E., Kashy, D. A., \& Smith, J. A. (2010). Preadoptive factors predicting lesbian, gay and heterosexual couples' relationship quality across the transition to adoptive parenthood. Journal of Family Psychology, 24, 221-232. https://doi.org/10. 1037/a0019615

Goodman, A., \& Greaves, E. (2010). Cohabitation, marriage and relationship stability. Institute for Fiscal Studies.

Hahlweg, K. (1996). Fragebogen zur Partnerschaftsdiagnostik (FPD) [Questionnaire for partnership diagnostics]. Verlag für Psychologie.

Holomberg, D., \& Blair, K. L. (2009). Sexual desire communication, satisfaction and preferences of men and women in same-sex versus mixed-sex relationships. Journal of Sex Research, 46, 57-66. https://doi.org/10.1080/00224490802645294

Huebner, D. M., Mandic, C. G., Mackaronis, J. E., Beougher, S. C., \& Hoff, C. C. (2012). The impact of parenting on gay male couples` relationships, sexuality and HIV risk. Couple and Family Psychology: Research and Practice, 1, 106-119. https://doi. org/10.1037/a0028687

Hsueh, A. C., Morrison, K. R., \& Doss, B. D. (2009). Qualitative reports of problems in cohabiting relationships: Comparisons to married and dating relationships. Journal of Family Psychology, 23, 236-246. https://doi.org/10.1037/a0015364

ILGA Europe (2019). ILGA Europe annual review. Retrieved from https://www.ilga-europe.org/rainboweurope

Janicka, I. (2008). Stosunki partnerskie w związkach niemałżeńskich [Partner relations in non-marital couples]. Przeglad Psychologiczny, 1, 37-53.

Janicka, I., \& Szymczak, W. (2017). Kwestionariusz Zaangażowania Interpersonalnego - polska adaptacja metody [Interpersonal Commitment Questionnaire - Polish adaptation]. Polskie Forum Psychologiczne, 2, 205-218.

Janicka, I., \& Szymczak, W. (2019). Can close romantic relationships last? The commitment of partners in married and cohabitant couples. Current Issues in Personality Psychology, 7, 203-211. https://doi. org/10.5114/cipp.2019.86129

Julien, D., Chartrand, E., Simard, M. C., Bouthillier, D., \& Bégin, J. (2003). Conflict, social support and relationship quality: an observational study of heterosexual, gay male and lesbian couples' communication. Journal of Family Psychology, 17, 419428. https://doi.org/10.1037/0893-3200.17.3.419

Kline, G. H., Stanley, S. M., Markman, H. J., OlmosGallo, P. A., Peters, M. S., Whitton, S. W., \& Prado, L. M. (2004). Timing is everything: Pre-engagement cohabitation and increased risk for poor marital outcomes. Journal of Family Psychology, 2, 311-318. https://doi.org/10.1037/0893-3200.18.2.311

Kurdek, L. A. (2004). Are gay and lesbian cohabiting couples really different from heterosexual married couples? Journal of Marriage and Family, 66, 880-900. https://doi.org/10.1111/j.0022-2445.2004. 00060.x 
Kurdek, L. A. (2005). What do we know about gay and lesbian couples? Current Directions in Psychological Science, 14, 251-254. https://doi.org/10.1111/ j.0963-7214.2005.00375.x

Kurdek, L. A. (2008). Change in relationship quality for partners from lesbian, gay male and heterosexual couples. Journal of Family Psychology, 22, 701-711. https://doi.org/10.1037/0893-3200.22.5.701

Lew-Starowicz, Z., \& Lew-Starowicz, M. (2014). Homoseksualizm [Homosexuality]. Wydawnictwo Lekarskie PZWL.

Lichter, D. T., \& Qian, Z. (2008). Serial cohabitation and the marital life course. Journal of Marriage and the Family, 70, 861-878. https://doi.org/ 10.1111/j.1741-3737.2008.00532.x

Majka-Rostek, D. (2012). Osoby LGB w związkach intymnych [LGB people in intimate relationships]. In G. Iniewicz, M. Mijas, \& B. Grabski (Eds.), Wprowadzenie do psychologii LGB [Introduction to LGB psychology] (pp. 199-216). Wydawnictwo Continuo.

McClelland, S. I. (2013). What do you mean when you say that you are sexually satisfied? A mixed methods study. Feminism \& Psychology, 24, 74-96. https://doi.org/10.1177/0959353513508392

McLanahan, S., \& Beck, A. (2010). Parental relationships in fragile families. The Future of Children, 20, 17-37. https://doi.org/10.1353/foc.2010.0007

Meyer, I. H. (2003). Prejudice, social stress, and mental health in lesbian, gay, and bisexual populations: Conceptual issues and research evidence. Psychological Bulletin, 129, 674-697. https://doi.org/ 10.1037/0033-2909.129.5.674

Mizielińska, J., Abramowicz, M., \& Stasińska, A. (2014). Rodziny z wyboru w Polsce [Families of choice in Poland]. PAN.

Mortensen, O., Torsheim, T., Melkevik, O., \& Thuen, F. (2012). Adding a baby to the equation. Married and cohabiting women `s relationship satisfaction in the transition to parenthood. Family Process, 51, 122-139. https://doi.org/10.1111/j.1545-5300.2012. 01384.x

Nave-Herz, R. (2002). Wandel und Kontinuität in der Bedeutung, in der Struktur und Stabilität von Ehe und Familie in Deutschland [Change and continuity in the meaning, structure and stability of marriage and family in Germany]. In R. NaveHerz (Ed.), Kontinuität und Wandel der Familie in Deutschland [Family continuity and change in Germany] (pp. 45-69). Enke.

Office for National Statistics (2015). Civil Partnerships in England and Wales: 2015. Marriages formed, civil partnerships formed and dissolved, and estimates of the population by marital status and living arrangements. Retrieved from https://www.ons.gov.uk/peoplepopulationandcommunity/birthsdeathsandmarriages/marriagecohabitationandcivilpartnerships/ bulletins/civilpartnershipsinenglandandwales/2015
Peplau, L. A., \& Ghavami, N. (2009). The relationships of lesbians, gay men and bisexuals. In $\mathrm{H}$. Reis \& S. Sprecher (Eds.), The encyclopedia of human relationships (pp. 1-4). Sage Publications.

Pryor, J., \& Roberts, J. (2005). What is commitment? How married and cohabiting parents talk about their relationship. Family Matters, 71, 24-31.

Ramirez, O. M., \& Brown, J. (2010). Attachment style, rules regarding sex, and couple satisfaction: A study of gay male couples. Australian and New Zealand Journal of Family Therapy, 31, 202-213. https://doi.org/10.1375/anft.31.2.202

Rhoades, G. K., Stanley, S. M., \& Markman, H. J. (2006). Pre-engagement cohabitation and gender asymmetry in marital commitment. Journal of Family Psychology, 20, 553-560. https://doi.org/ 10.1037/0893-3200.20.4.553

Rhoades, G. K., Stanley, S. M., \& Markman, H. J. (2012). The impact of the transition to cohabitation on relationship functioning: Cross-sectional and longitudinal findings Journal of Family Psychology, 26, 348-358. https://doi.org/10.1037/a0028316

Roisman, G. I., Clausell, E., Holland, A., Fortuna, K., \& Elieff, C. (2008). Adult romantic relationships as contexts of human development: a multimethod comparison of same-sex couples with oppositesex dating, engaged and married dyads. Developmental Psychology, 44, 91-101. https://doi.org/ 10.1037/0012-1649.44.1.91

Sink, C. A., \& Mvududu, N. H. (2010). Statistical power, sampling, and effect sizes: Three keys to research relevancy. Counseling Outcome Research and Evaluation, 1, 1-18. https://doi.org/10.1177/ 2150137810373613

Smock, P. (2000). Cohabitation in the United States: an appraisal of research themes, findings and implications. Annual Review of Sociology, 26, 1-20. https://doi.org/10.1146/annurev.soc.26.1.1

Solomon, S. E., Balsam, K. F., Beauchaine, T. P., \& Rothblum, E. D. (2008). Three-year follow-up of same-sex couples who had civil unions in Vermont, same-sex couples not in civil unions and heterosexual married couples. Developmental Psychology, 44, 102-116. https://doi.org/10.1037/0012-1649. 44.1.102

Stanley, S. M., \& Markman, H. J. (1992). Assessing commitment in personal relationships. Journal of Marriage and the Family, 54, 595-608. https://doi. org/10.2307/353245

Stanley, S. M., Rhoades, G. K., \& Markman, H. J. (2006). Sliding versus deciding: Inertia and the premarital cohabitation effect. Family Relations, 55, 499-509. https://doi.org/10.1111/j.1741-3729.2006.00418.x

Stanley, S. M., Whitton, S. W., \& Markman, H. J. (2004). Maybe I do: Interpersonal commitment and premarital or non-marital cohabitation. Journal of Family Issues, 25, 496-519. https://doi.org/ $10.1177 / 0192513 \times 03257797$ 
Świder, M., \& Winiewski, M. (2017). Sytuacja spoteczna osób LGBTA w Polsce. Raport za lata 2015-2016 [The social situation of LGBTA people in Poland. Report for 2015-2016]. Kampania Przeciw Homofobii.

Vanderlaan, D. P., \& Vasey, P. L. (2008). Mate retention behavior of men and women heterosexual and homosexual relationships. Archives of Sexual Behavior, 37, 572-585. https://doi.org/10.1007/s10508006-9139-y

Whitton, S. W., Kuryluk, A. D., \& Khaddouma, M. (2015). Legal and social ceremonies to formalize same-sex relationships: Associations with commitment, social support, and relationship outcomes. Couple and Family Psychology: Research and Practice, 4, 161-176. https://doi.org/10.1037/cfp0000045

Whitton, S., Dyar, C., Newcomb, M., \& Mustanski, B. (2018). Romantic involvement: a protective factor for psychological health in racially-diverse young sexual minorities. Journal of Abnormal Psychology, 127, 265-275. https://doi.org/10.1037/abn0000332

Winer, B. J., Brown, D. R., \& Michels, K. M. (1991). Statistical principles in experimental design. Third edition. McGraw-Hill.

Xu, X., Hudspeth, C. D., \& Bartkowski, J. P. (2006). The role of cohabitation in remarriage. Journal of Marriage and Family, 68, 261-274. https://doi. org/10.1111/j.1741-3737.2006.00251.x 